\title{
The intrinsic or the extrinsic pathways of apoptosis in the epidermis after cladribine application?
}

\author{
Patrycja Chylinska-Wrzos ${ }^{1}$, Ewelina Wawryk-Gawda ${ }^{1}$, Marta Lis-Sochocka ${ }^{1}$, Marian Jedrych ${ }^{2}$, \\ Miroslaw Lancut ${ }^{1}$, Kamila Bulak ${ }^{1}$, Joanna Leszcz-Stankiewicz ${ }^{3}$, Barbara Jodlowska-Jedrych ${ }^{1}$

\footnotetext{
${ }^{1}$ Department of Histology and Embryology with Experimental Cytology Unit, Medical University of Lublin, Lublin, Poland

${ }^{2}$ Department of Mathematics and Biostatistics, Medical University of Lublin, Lublin, Poland

${ }^{3}$ Dental and Implant Center, Lublin, Poland

Email: barbara.jjedrych@umlub.pl
}

Received 28 January 2013; revised 28 February 2013; accepted 3 March 2013

\begin{abstract}
Purpose: This study was aimed to assess the expression of caspase 8 and caspase 9 in the epidermis, during apoptosis after cladribine administration. Materials and Methods: The experiment was carried on 10 Wistar rats. The animals were placed into 2 groups: control group and experimental group. Animals in the control group, in addition to standard feed and water, were injected with a physiological salt in a quantity corresponding to the drug dosage, over the course of the experiment. The experimental group animals were treated with cladribine in the dose of $0.07 \mathrm{mg} / \mathrm{kg} / 24 \mathrm{~h}$, for 6 consecutive days in the morning, in 3 cycles with a 5-week gap in administering the drug. After the completion of the experiment, the animals were decapitated, and full thickness slices of skin were taken from all the rats for immunohistochemical study. The results of the statistical surveys were analysed in Statistica 10.0. The difference in intensity of expression of caspase 9 and caspase 8 in the groups were investigated using the Chi-quadrat test. Statistical significance was considered at $\mathbf{p}<\mathbf{0 . 0 5}$. Results: The statistical analysis found significant correlation in expression of caspase 9 between examined groups $(p<0.0001)$. There were no statistical relationships in the presence of the expression of caspase 8 between examined groups $(p=0.0526)$. Conclusion: Our findings suggest that mechanism of apoptosis in the rats' epidermis, induced by cladribine given in the scheme used in the treatment of MS in humans, involves caspase 9 activity. This means that 2-CdA initiates the intrinsic apoptosis pathway.
\end{abstract}

Keywords: Cladribine; Apoptosis; Caspase 8; Caspase 9; Epidermis

\section{INTRODUCTION}

Cladribine (2-CdA, 2-chloro-2'-deoxyadenosine,
$\mathrm{C}_{10} \mathrm{H}_{12} \mathrm{CIN}_{5} \mathrm{O}_{3}$ ) is a synthetic purine analogue (AN) with high immunosuppressive and antineoplastic activity $[1,2]$. The molecule of 2-CdA was first investigated at the Scripps Research Institute (La Jolla, Calif) in the 1970s [3-5], and as reported Saven et al., cladribine was first synthesized by Christensen et al., who used the substitution of the hydrogen atom by the alkyl group in the 2,6dichloropurine [6].

In 1980, 2-CdA was accepted by the FDA in HCL therapy at any stage of the disease [4] but good results are also obtained in treating chronic lymphocytic leukemia and non-Hodgkin lymphoma [7].

The effectiveness of cladribine has been also confirmed in other hematological malignancies and autoimmune diseases, such as multiple sclerosis, rheumatoid arthritis, systemic lupus erythematus-associated glomerulonephritis and psoriasis $[1,3,4,8]$.

Multiple Sclerosis is a chronic inflammatory-demyelinating disease of the central nervous system of autoimmune substrate which develops most often between 20 and 40 years of age [9]. In the development of disease are involved autoreactive immune cells, cytokines, macrophages and antibodies [10]. Some studies indicate that autoreactive $\mathrm{CD}^{+} \mathrm{T}$ lymphocytes are main cells involved in the emergence of the disease $[11,12]$.

As reported by Leist et al., cladribine administration in tablet form leads to a sustainable reduction in the number of lymphocytes [4]. This condition continues until 3 - 4 weeks after the end of the treatment $[3,4]$.

2-CdA is a chlorinated analog of deoxyadenosine in which the hydrogen atom has been replaced by a chlorine atom at the 2 position of the purine ring. This gives it resistance to the action of the adenosine deaminase (ADA) which is involved in the metabolism of purines $[3,4,6]$. Like other AN, 2-CdA has selective toxicity towards lymphocytes and monocytes [5].

2-CdA gets to the destination cells via specific nucleoside transporter proteins. In cells, cladribine undergoes intracellular phosphorylation by deoxycytidine kinase 
(DCK), to monophosphate 2-chlorodeoxyadenosine (2CdAMP), subsequently to diphosphate 2-chlorodeoxyadenosine (2-CdADP), and then to triphosphate 2-chlorodeoxadenosine (2-CdATP), which is the active form. 2-CdATP works on both dividing and non-dividing cells $[1,2,4-6,8,13]$.

The triphosphate form is incorporated into the DNA strand. This induces changes in the double helix structure of deoxyribonucleic acid and consequently leads to cell death. Moreover, inhibition of DNA repair in resting cells leads to an accumulation of DNA strand breaks, which brings about a poly (ADP-ribose) polymerase response that induces improvements in the corrective mechanisms. Further studies have, as well, shown that exposure of non-dividing cells to 2-CdA leads to a reduction of the intracellular pool of NAD and ATP that is associated with apoptosis $[14,15]$. In addition, 2-CdATP inhibits the activity of the polymerase DNA, ribonucleotide reductase and enzymes involved in the DNA and RNA synthesis and repair [4,5]. Inhibition of DNA repair and accumulation of cracks in its structure leads to the expression of p53 protein, which plays a crucial role in the regulation of cell cycle and apoptosis. Numerous studies indicate that cladribine kills both cells in the dividing phase and in the resting phase, via programmed cell death $[1,2]$.

Mechanism of 2-CdA action is based on the induction of apoptosis in the target cells. Apoptosis is the major form of cell death. It is physiological process which is associated with organogenesis, homeostasis of organism, development of tissues and organs. Moreover apoptosis regulates immunological response and the elimination of damage cells $[16,17]$. The process of programmed cell death starts in cell nucleus. Firstly nucleus chromatin condenses and DNA is fragmented on the segments of length 180 - 200 alkali pairs. The nucleus volume is smaller and it is shrunken. Then the cell is fragmented into "apoptotic bodies" which contain pieces of chromatin, cell organelles and cytosol. This structures are eliminated by phagocytosis [18-23]. Apoptosis can proceed in two main pathways. First way can be called as receptor, extrinsic, or cytoplasmic pathway and is mediated by death receptors. Death receptors belong to superfamily of TNF receptors which include e.g. Fas, CD95, TRAIL-R1 and TRAIL-R2 receptors. Second way is called as intrinsic, stress or mitochondrial pathway. The intrinsic apoptosis pathway is mediated by genomic stress, metabolic stress, and another stimuli which lead to release of cytochrome $\mathrm{c}$ from mitochondria to cytosol and active death signal $[18,19,22]$.

Apoptosis induced by 2-CdA can be mediated by the death receptors (Fas/CD95), either by way of the extrinsic pathway or through the intrinsic pathway involving the mitochondria $[1,24]$. Independently of the apoptosis pathways, the execution of this process proceeds with the participation of enzymes called caspases. Caspases belong to a cysteine-dependent aspartate-directed proteases. Caspases exist in all cells as zymogens latent pro-forms. This proenzymes are a single 32 - $55 \mathrm{kDa}$ polypeptide chain with three domains: 3 - $24 \mathrm{kDa}$ NH2-terminus prodomain, large domain about $20 \mathrm{kDa}$ called p20 and small C-terminal domain about $10 \mathrm{kDa}$ called p10. During apoptosis caspases are transformed to the active form. To this time, there are known 14 members of caspase family $[23,25-28]$. The enzymes can be classified dependent on the structure of domain length and their functions. Based on this, caspases are characterised as: initiator (activator) caspases e.g. $-2,-8,-9$, and caspase -10 , executioner or effector caspases like caspase-3, -6 and -7 . And third group is called inflammatory mediator caspases which include caspase- $1,-4,-5,-11,-12,-13$ and $-14[23,25$, 29].

During apoptosis activated initiator caspases like caspase- 8 and -9 , stimulate the executioner caspases. This cascade of caspases can mediate the programmed cell death by the mitochondrial or receptor pathway [27]. Activation of procaspase 8 started after induction of TNF death receptors. Then procaspase 8 is enabled to death receptor by special proteins and undergoes oligomerization to its active form which triggers apoptosis. Caspase- 8 is a mediator of the extrinsic way of apoptosis $[25,27]$. However caspase-9 is an intrinsic pathway marker. During this way, under stress stimuli, cytochrome c releases from mitochondria to cytosol. In cytosol in the presence of dATP/ATP, cytochrome c, Apaf-1 and procaspase- 9 connect together to form apoptosome complex which results in procaspase- 9 activation, initiating the cell death $[25,26]$.

Because the available literature presents no data on the impact of the drug on the skin, we decided to examine the possible impact of the investigated substance on this organ.

Besides of this, numerous studies show that the mechanism of 2-CdA action is based on the induction of programmed cell death, it seems necessary to understand how chosen apoptosis proteins behave. On the basis of tests carried out by Klöpfer, Marzo and Nomura, it can be concluded that apoptosis induced by cladribine (depending on the cell line) follows different apoptosis pathways [30-32]. Therefore, using the immunohistochemistry method, we have been analyzed the expression of caspase 9 (which is an intrinsic pathway marker) and caspase 8 (which is a mediator of the extrinsic way of apoptosis).

\section{MATERIALS AND METHODS}

The experiment was carried on 10 female Wistar rats. 
The rats' middle body mass was 250 - $300 \mathrm{~g}$. The animals were placed into 2 groups: control group and experimental groups. Each groups consisted of 5 animals. The animals were handled accordingly to ethical standards set out by the National Institute of Health Guidelines for the Care and Use of Laboratory Animals and the European Community Council Directive of 24 November 1986 for Care and Use of Laboratory Animals (86/ 609/EEC), and approved by the local ethics committee.

Animals in the control group, in addition to standard feed and water, were injected with a physiological salt in a quantity corresponding to the drug dosage, over the course of the experiment.

The experimental group animals were treated with cladribine (Biodribin, produced by the Institute of Biotechnology and Antibiotics) in the dose of $0.07 \mathrm{mg} / \mathrm{kg} / 24 \mathrm{~h}$, for 6 consecutive days in the morning at 9 a.m., in 3 cycles with a 5 week gap in administering the drug. This is a scheme corresponding to the treatment of multiple sclerosis in humans. The drug was administered subcutaneously by syringe and needle, interchangeably in the left or right side at the height of the lumbar spine. The test material was downloaded $24 \mathrm{~h}$ after administration of the last dose of the drug.

During the experiment, the rats were kept in the same conditions. The relative air humidity was $50 \%-60 \%$, the environmental temperature was $20^{\circ} \mathrm{C}+/-1^{\circ} \mathrm{C}$, and a $24-$ hour cycle was kept ( $12 \mathrm{~h}$ day, $12 \mathrm{~h}$ night). The rats were given standard granulated fodder (LSM) and drinking water ad libitum. In addition, rats were kept in cages (Tecniplast ${ }^{\circledR}$ ) of $0.5 \mathrm{~m}^{2}$ area. Stress factors were reduced to a minimum.

To carry out the research, consent no 126/2001 was obtained from the Local Medical University of Lublin Bioethical Committee.

After the completion of the experiment, the animals were decapitated, and full thickness slices of skin (of an area $1 \mathrm{~cm}^{2}$ ) were taken from all the rats for immunohistochemical study.

In order to assess the degree of apoptosis in the test material, an immunohistochemistry reaction was carried out with the use of properly diluted primary antibodies, Sigma $^{\circledR}$, being directed against the tested antigens. In this, caspase 8 (ANTI-CASP8, HPA008936-100UL, Antibody Produced in Rabbit, dilution: 1:50) and caspase 9 (ANTI-, HPA001473-, 100UL CASP9 Antibody Produced in Rabbit, dilution: 1:40) were used.

All Immunohistochemistry reactions undertaken to evaluate the expression of tested proteins were carried out according to the indirect immunoperoxidase method. In so doing, paraffin fragments of $5 \mu \mathrm{m}$ thickness were imposed on Polysine ${ }^{\circledR}$ Slides and incubated overnight at a $58^{\circ} \mathrm{C}$ temperature. They were then dehydrated in ethyl alcohol with increasing concentration, and placed in xy- lene. In order to block the activity of endogenous peroxidase, the samples were rinsed for 5 minutes in a $3 \%$ hydrogen peroxide in methanol. Successive preparations were subsequently washed in distilled water and in a solution of TBS. After this, antigens channels were unmasked using the thermal process. Sections were microwaved $(800 \mathrm{~V})$ in $0.01 \mathrm{M}$ citrate buffer, $\mathrm{pH} 6.0$, by way of 3 five minute cycles. After washing in distilled water, to block all places which could bind the used antibody, the samples were then incubated for 30 minutes with inactive serum (Normal Diluted Serum). Following this, they were rinsed in a solution of TBS. The material were incubated for 24 -hour at $8^{\circ} \mathrm{C}$, with the primary antibodies. In order to give visibility, NovoLinkTM were used. After that, the samples were rinsed in a solution of TBS and mottled by chromogen-3-3'diaminobenzidine (Novolink DAB), which induced a bronze colouring of the reaction product. In addition, at the end of the treatment, the sample's cell nuclei were stained by Meyer hematoxylin.

To provide negative control, in regard to all sections of all the research groups for the evaluated antibodies: treatment with caspases 8 and 9 were carried out by the same method, by passing the primary antibody.

Evaluation of the material was undertaken using an Olympus BX41 with digital camera image DP25. Calculations were made in $\mathrm{Cell}^{\wedge} \mathrm{D}$.

In order to determine the intensity of the immunohistochemistry reaction, 3 areas of $400 \times$ vision were selected, and three trials of 100 cell-counts were analyzed. Areas with a positive response was assessed in terms of the intensity of immunohistochemistry expression at $1(+)$ being a weak reaction, $2(++)$ being the average response and $3(+++)$ being a strong reaction. The results of the statistical surveys were analyzed in Statistica 10.0 [33]. The difference in intensity of expression of caspase 9 and caspase 8 in the groups were investigated using the Chi-quadrat test. Statistical significance was considered at $\mathrm{p}<0.05$.

\section{RESULTS}

\subsection{Caspase 9 (Figure 1 and Figure 2)}

Microscopic analysis of control group specimen revealed brown grain in the cells cytoplasm. A positive reaction of caspase 9 was weak, assessed at $1(+)$. Just single cells from basal and prickle cells layer showed immunoprecipitates. Moreover, negative reaction was visible in some cells (Figure 1).

In experimental group a positive reaction of examined protein was observed in the cytoplasm of cells from basal layer. Reaction was stronger in comparison to the control group. The expression of caspase 9 was assessed at $3(+++)$ (Figure 2). Other cells showed negative or trace reaction. 


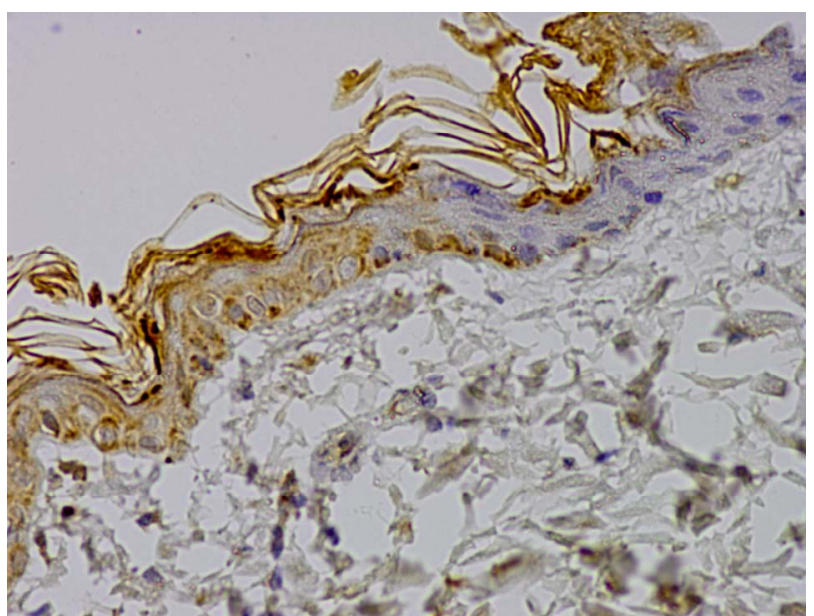

Figure 1. Control group. IHC caspase 9 reaction (+), Magn. $\times 400$.

On the basis of the statistical analysis in regard to expression of caspase 9, we found significant correlation between examined groups (Table 1). The difference in the presence of the expression of caspase 9 between the control group and the experimental group was $\mathrm{p}<$ 0.0001 .

A negative reaction was visible in epidermis of both group. In the control group more than $63 \%$ of the cells showed a negative reaction, while in the experimental group, this was slightly more than $31 \%$. Most of the cells in experimental group expressing caspase 9 activity $(68.33 \%)$. In this group, more than $22 \%$ of cells showed a strong expression of protein, assessed at $3(+++)$, compared to the control group (Figure 3). In both examined groups some part of cells showed weak reaction, assessed at $1(+)$. In control group it was $28 \%$ of cells and in experimental group $27 \%$ of cells (Table 1).

\subsection{Caspase 8}

In order to assess the progress of the extrinsic apoptosis pathway in the test material, we assessed the expression of caspase 8 .

On the control group specimen immunohistochemistry reaction was negative. Weak reaction, assessed at $1(+)$ was visible in the cytoplasm of single cells, mainly in the basal layer (Figure 4).

Microscopic analysis of experimental group specimen, revealed weak caspase 8 expression. Immunohistochemistry reaction was observed in the cells cytoplasm. Moreover, some of cells showed negative reaction of examined protein (Figure 5).

On the basis of the received results, there were no statistical relationships between examined groups (Table 2). The difference in the presence of the expression of caspase 8 between the control group and experimental group was not statistically significant $\mathrm{p}=0.0526$.

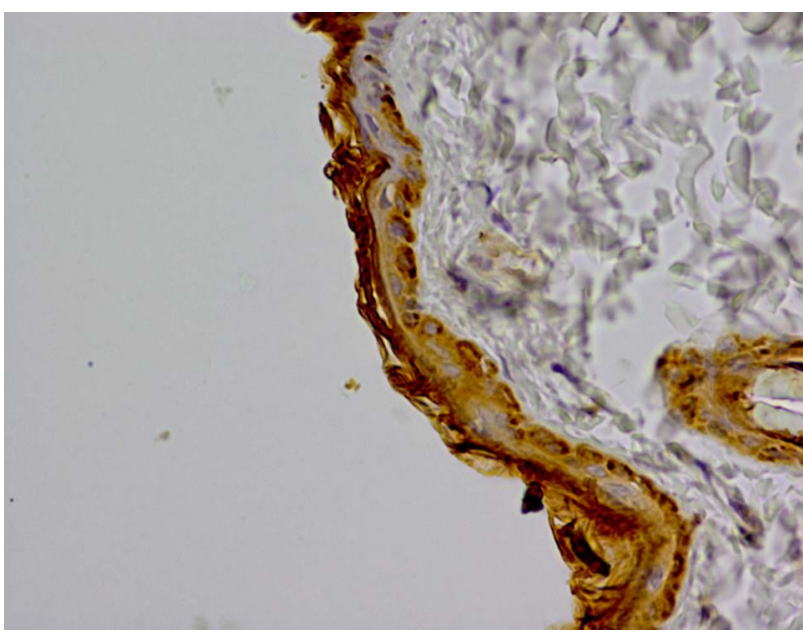

Figure 2. Experimental group. IHC caspase 9 reaction $(+)$, Magn. $\times 400$.

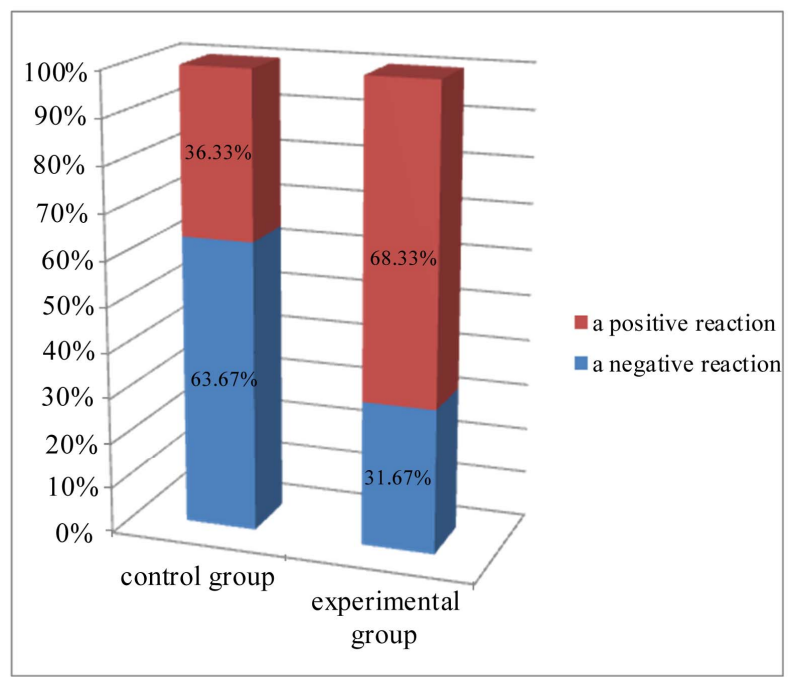

Figure 3. Expression of caspase 9 in the investigated groups.

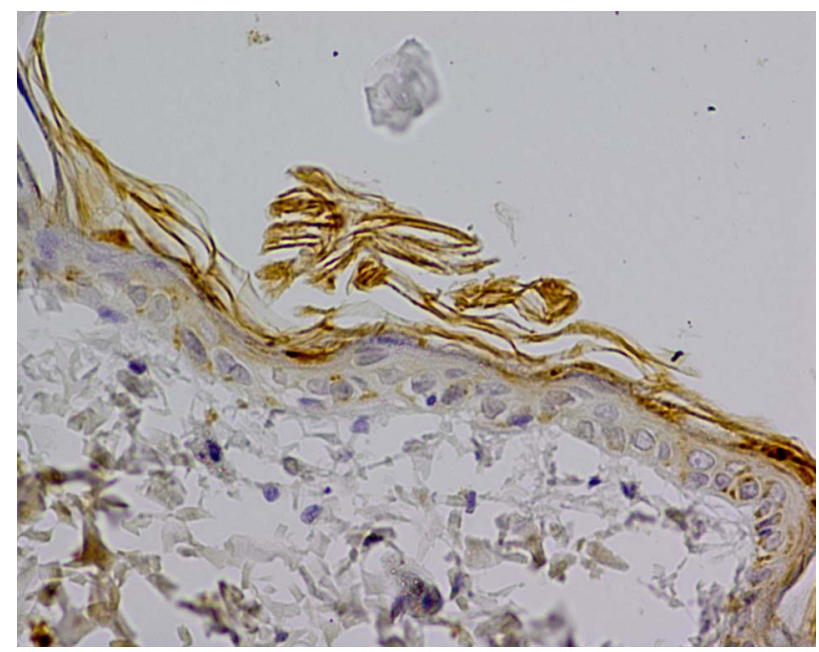


Figure 4. Control group. IHC caspase 8 reaction $(+)$, Magn. $\times 400$.

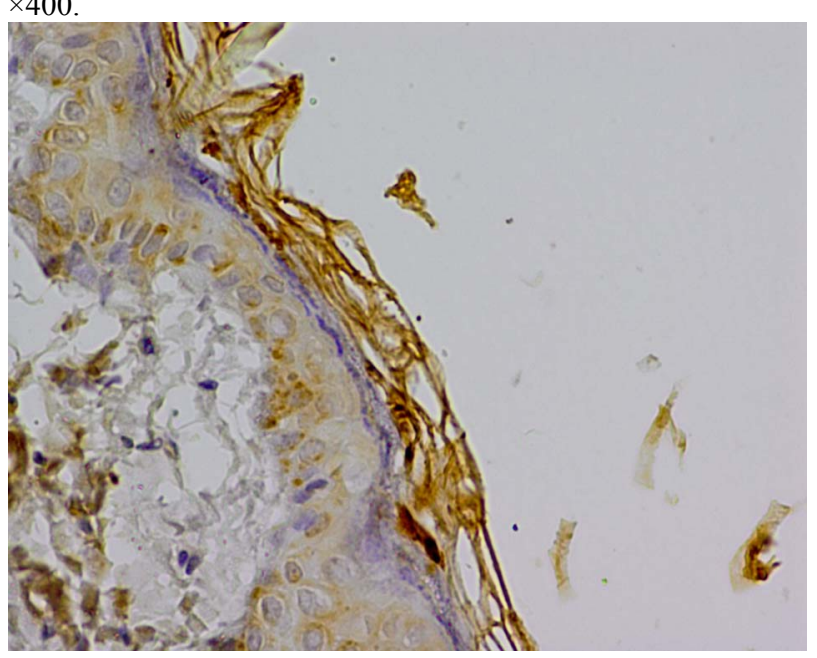

Figure 5. Experimental group. IHC caspase 8 reaction $(+)$, Magn. $\times 400$.

Table 1. Expression and intensity of caspase 9 immunohistochemistry reaction in the investigated groups.

\begin{tabular}{|c|c|c|c|c|c|c|}
\hline \multirow{2}{*}{\multicolumn{2}{|c|}{ Investigated groups }} & \multicolumn{5}{|c|}{ Expression of caspase 9 in the epidermis } \\
\hline & & $(-)$ & $1(+)$ & $2(++)$ & $3(+++)$ & Together \\
\hline \multirow{2}{*}{ Control group } & Number & 191 & 84 & 22 & 3 & 300 \\
\hline & $\%$ & $63.67 \%$ & $28.00 \%$ & $7.33 \%$ & $1.00 \%$ & \\
\hline \multirow{2}{*}{$\begin{array}{l}\text { Experimental } \\
\text { group }\end{array}$} & Number & 95 & 81 & 56 & 68 & 300 \\
\hline & $\%$ & $31.67 \%$ & $27.00 \%$ & $18.67 \%$ & $22.67 \%$ & \\
\hline
\end{tabular}

$(-)$ negative reaction, $1(+)$ weak reaction, $2(++)$ the average response, 3 $(+++)$ a strong reaction.

Table 2. Expression and intensity of caspase 8 immunohistochemistry reaction in the investigated groups.

\begin{tabular}{ccccccc}
\hline \multirow{2}{*}{ Investigated groups } & \multicolumn{5}{c}{ Expression of caspase 8 in the epidermis } \\
\cline { 2 - 6 } & $(-)$ & $1(+)$ & $2(++)$ & $3(+++)$ & Together \\
\cline { 1 - 4 } $\begin{array}{c}\text { Control } \\
\text { group }\end{array}$ & Number & 282 & 18 & 0 & 0 & 300 \\
& $\%$ & $94.00 \%$ & $6.00 \%$ & $0 \%$ & $0 \%$ & \\
$\begin{array}{c}\text { Experimental } \\
\text { group }\end{array}$ & Number & 269 & 31 & 0 & 0 & 300 \\
\hline
\end{tabular}

$(-)$ negative reaction, $1(+)$ weak reaction, $2(++)$ the average response, 3 $(+++)$ a strong reaction.

On the basis of the analysis of microscopic and statistical results of research, it was found that most cells in the epidermis showed a negative expression of caspase 8 , means $94 \%$ in the control group and more than $89 \%$ in the experimental group (Figure 6). Positive, weak reaction, assessed at $1(+)$, showed $6 \%$ cells from control group and more than $10 \%$ cells from experimental group.
There were not cells with average response and with strong reaction (Table 2 and Figure 6).

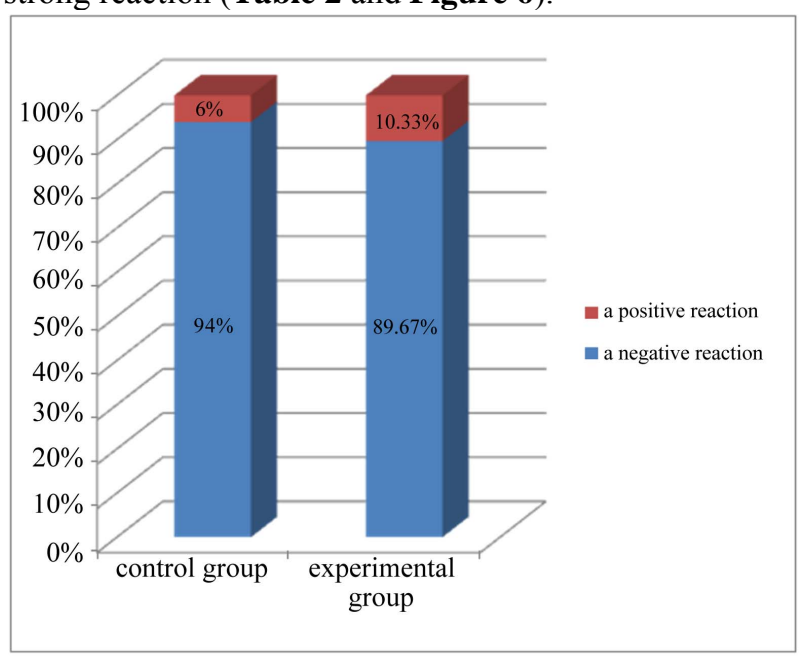

Figure 6. Expression of caspase 8 in the investigated groups.

\section{DISCUSSION}

Cladribine is deoxyadenosine analog which is used mainly for the treatment of hairy cell leukemia, some hematologic malignancies and autoimmune diseases [4]. Mechanism of 2-CdA action is based on the induction of apoptosis in the target cells [1,2]. Nomura investigated DNA fragmentation in MOLT-4 cells after incubation with 5 $\mu \mathrm{M}$ of 2-CdA in different time [32]. It has been showed that cladribine induced DNA strand breaks with 3'-OH ends which means that endonuclease started DNA fragmentation what is characteristic for apoptosis.

In the course of apoptosis a family of cysteine proteases called caspases is involved. Two main apoptosis pathways are known, the intrinsic pathway which involving mitochondria and the extrinsic pathway associated with activation of death receptors of the TNF family [26]. Caspase 8 is apical enzyme in the extrinsic way and caspase 9 is the mitochondrial way marker. Despite of many study, the role of individual caspases in apoptosis induced by 2-CdA is still controversial and unclear.

One of the first reports on the death receptor and the expression of caspase 8 after cladribine treatment were demonstrated by Nomura et al. [32]. The flow cytometry and Western blotting analysis confirmed that the expression of Fas and Fas-L on the MOLT-4 cell surface was stimulated after 2-CdA treatment. Moreover, active form of procaspase- 8 were detected during Western blot analysis. Fragmentation of procaspase 8 started at $6 \mathrm{~h}$ treatment. The study demonstrates that stimulation of Fas/Fas-L system by 2-CdA induced apoptosis by caspase 8 in MOLT- 4 cells.

Marzo et al. in 2001 have studied the role of selected 
caspases in the apoptosis induced by 2-CdA in JM1, Jurkat and U937 cell lines [31]. They observed expression of caspase 8 in all cell lines. Moreover authors used anti-Fas blocking antibodies and noted that in Jurkat and U937 cells apoptosis was not inhibited by this blocker. So they excluded the possibility that apoptosis initiated by cladribine was mediated by Fas/FasL system in this cell lines. Over wise, the activation of caspase 9 in examined cell lines was investigated. The activity of large subunit $35 / 37 \mathrm{kDa}$ of this protein increased in cells after 2-CdA application.

Similar results were obtained by Conrad et al. The experiment was performed on Jurkat cell line [34]. Cells were exposure to $25 \mu \mathrm{M} 2$-CdA by $6 \mathrm{~h}$ and analyzed by Western blotting. The study demonstrates cleavage of pro-caspases 3,8 and 9 , indicating of this capsases activation. Further Jurkat cells were treated with a pancaspase inhibitor-z-VAD-fmk which a near complete inhibited apoptosis initiated by $2-\mathrm{CdA}$. So data indicating that examined caspases are involved in the mechanism of cell death caused by cladribine in Jurkat cell lines. Furthermore, similar to Marzo results, caspase- 8 was not activated by death receptor signal. 2-CdA induced DNA fragmentation was not observed after exposure to antiFas ligand or anti-TRAIL neutralizing antibodies.

In our study, we received a different results on caspase 8 expression than Marzo et al. and Nomura et al. [31,32]. The experiment was carried on female Wistar rats. Cladribine was administered in the dose of $0.07 \mathrm{mg} / \mathrm{kg} / 24 \mathrm{~h}$, for 6 consecutive days in the morning at 9 a.m., in 3 cycles with a 5-week gap. Our study demonstrates no statistical relationships in the expression of caspase 8 in the epidermis between examined group. Microscopic analysis and statistical results found that most cells in the epidermis showed a negative immunohistochemical reaction of this protein. These results indicated that caspase 8 is not involved in the apoptosis initiated by $2-\mathrm{CdA}$ in epidermis.

Whereas on the basis of the statistical analysis in regard to expression of caspase 9, we found significant correlation between examined groups. The difference in the presence of the expression of caspase 9 between the control group and the experimental group was $\mathrm{p}<0.0001$. More than $68 \%$ of the keratinocytes in experimental group expressing caspase 9 activity and more than $22 \%$ of cells showed a strong intensity of reaction, assessed at $3(+++)$, compared to the control group. This result indicated that capsase 9 is activated in the epidermis upon 2-CdA treatment. Thus, analysis of the level of the expression of caspase- 8 and -9 suggests that the process of apoptosis in epidermal cells treated with 2-CdA, involves caspase 9 , so it is intrinsic pathway.

Our result are confirmed by the Klöpfer et al. Authors examined Jurkat $\mathrm{T}$ cells lacking caspase 8 [30]. Cladribine was used in dose from 2.5 to $20 \mu \mathrm{M}$. $72 \mathrm{~h}$ after 2-CdA treatment, both Jurkat cells, caspase 8 -/- and wild-type, showed DNA fragmentation. To confirm this results caspase 8 inhibitor zIETD-fmk, was used and evidenced that cladribine induced apoptosis independent of capsase 8. Lack of this protein did not prevented mitochondrial permeability. Caspase 8 -/- and wild-type cells, $24 \mathrm{~h}$ after 2-CdA application, in Western blot analysis showed active subunit of caspase 3 and appearance of the $37 \mathrm{kDa}$ subunit of caspase 9. Additionally, they investigated another cell line-MOLT-3 and authors obtained similar results. Caspase 8 inhibitor did not prevented DNA fragmentation in the cells after 2-CdA treatment.

Similar results can also be found in the Pérez-Galán et $a l$. work [35]. They investigated the role of selected caspases in mechanism of apoptosis induced by $2-\mathrm{CdA}$ in cells from patients of B cell chronic lymphocytic leukemia. Cells were designated as 'sensitive' and 'resistant' depending on response to the cladribine. Activation of including caspases 8 and 9, were determined in cells from sensitive patient. And no decrease in the intensity of this enzymes were observed in poorly responding cells.

Different results on the expression of caspases 9 and 8 after 2-CdA treatment have been received by Ceruti et al. [36]. The experiment was carried on the Human Astrocytoma Cell treated with 2-CdA. No significant stimulation of caspase 9 activity has been obtained. After $20 \mathrm{~h}$, when apoptosis already started, a small activation of capsase 9 has been detected. These results have been confirmed in Western blot analysis which revealed no activation of pro-caspase 9 form and its active subunit. Similar effects were obtained for caspase 8 . So they suggested that 2-CdA induces apoptosis in Human Astrocytoma Cells but does not involve activation of caspases 9 and 8 .

Our study demonstrated that mechanism of apoptosis in the rats' epidermis cells, induced by cladribine given in the schema used in the treatment of MS in humans, involves caspase 9 activity. This means that 2-CdA initiates the intrinsic apoptosis pathway.

On the basis of our results and results obtained by another authors, it can be concluded that depending on the cell lines, apoptosis initiated by cladribine proceeds with the participation of different caspases. Thus, evaluation of the role and activity of selected caspases associated with the intrinsic and extrinsic pathways constitute one of the major problems of research in this field.

What is more, knowing the mechanism of 2-CdA action and how 2-CdA initiated apoptosis in epidermis, will enable the development of more effectively therapeutic 
strategies and it can reduce the side effects during treatment. However, the obtained data need to be expanded, especially with studies on humans, in order to assess the impact of cladribine upon the male and female skin.

\section{REFERENCES}

[1] Robak, T., Lech-Maranda, E., Korycka, A. and Robak, E. (2006) Purine nucleoside analogs as immunosuppressive and antineoplastic agents: Mechanism of action and clinical activity. Current Medicinal Chemistry, 13, 31653189. doi:10.2174/092986706778742918

[2] Robak, T., Korycka, A., Lech-Maranda, E. and Robak, P. (2009) Current status of older and new purine nucleoside analogues in the treatment of lymphoproliferative diseases. Molecules, 14, 1183-1226.

doi:10.3390/molecules 14031183

[3] Leist, T.P. and Vermersch, P. (2007) The potential role for cladribine in the treatment of multiple sclerosis: Clinical experience and development of an oral tablet formulation. Current Medical Research \& Opinion, 23, 26672676. doi:10.1185/030079907X233142

[4] Leist, T.P. and Weissert, R. (2011) Cladribine: Mode of action and implications for treatment of multiple sclerosis. Clinical Neuropharmacology, 34, 28-35. doi: 10.1097/WNF.0b013e318204cd90

[5] Spurgeon, S., Yu, M., Phillips, J.D. and Epner, E.M. (2009) Cladribine: Not just another purine analogue? Expert Opinion on Investigational Drugs, 18, 1169-1181. doi:10.1517/13543780903071038

[6] Saven, A. and Piro, L.D. (1994) 2-Chlorodeoxyadenosine: A newer purine analog active in the treatment of indolent lymphoid malignancies. Annals of Internal Medicine, 120, 784-791.

[7] http://www.abcleki.pl/leki/biodribin

[8] Hartung, H.-P., Aktas, O., Kieseier, B. and Comi, G. (2010) Development of oral cladribine for the treatment of multiple sclerosis. Journal of Neurology, 257, 163-170. doi:10.1007/s00415-009-5359-0

[9] Maciejek, Z. (2005) Diagnostyka stwardnienia rozsianego. Farmakoterapia w Psychiatrii i Neurologii, 3, 209-217.

[10] Gasperini, C., Ruggieri, S. and Pozzilli, C. (2010) Emerging oral treatments in multiple sclerosis-clinical utility of cladribine tablets. Therapeutics and Clinical Risk Management, 6, 391-399.

[11] Kasper, L.H. and Shoemaker, J. (2010) Multiple sclerosis immunology. The healthy immune system vs the MS immune system. Neurology, 74, S2-S8. doi:10.1212/WNL.0b013e3181c97c8f

[12] Losy, J. (2004) Patogeneza oraz aktualne kryteria diagnostyczne stwardnienia rozsianego. Neurologia i Psychiatria, 4, 53-56.

[13] Crews, K.R., Wimmer, P.S., Hudson, J.Q., Howard, S.C., Ribeiro, R.C. and Razzouk, B.I. (2002) Pharmacokinetics of 2-chlorodeoxyadenosine in a child undergoing hemo- filtration and hemodialysis for acute renal failure. Journal of Pediatric Hematology/Oncology, 24, 677-680. doi:10.1097/00043426-200211000-00016

[14] Ewald, B., Sampath, D. and Plunkett, W. (2008) Nucleoside analogs: Molecular mechanisms signaling cell death. Oncogene, 27, 6522-6537. doi:10.1038/onc.2008.316

[15] Johnston, J.B. (2011) Mechanism of action of pentostatin and cladribine in hairy cell leukemia. Leuk Lymphoma, 52, 43-45. doi:10.3109/10428194.2011.570394

[16] Stańczyk, M. and Majsterek, I. (2008) Apoptoza-cel ukierunkowanej terapii przeciwnowotworowej. Postępy Biologii Komórki, 35, 467-484.

[17] Stępień, A., Izdebska, M. and Grzanka, A. (2007) Rodzaje śmierci komórki. Postęy Higieny i Medycyny Doświadczalnej, 61, 420-428. http://www.phmd.pl/fulltxthtml.php?ICID=490830

[18] Badowska-Kozakiewicz, A.M. and Malicka, E. (2009) Apoptoza w nowotworach gruczołu sutkowego u psów. Życie Weterynaryjne, 84, 902-905.

[19] Bielak-Żmijewska, A. (2003) Mechanizmy odporności komórek nowotworowych na apoptozę. Kosmos Problemy Nauk Biologicznych, 52, 157-171.

[20] Helewski, K.J., Kowalczyk-Ziomek, G.I. and Konecki, J. (2006) Apoptoza i martwica-dwie drogi do jednego celu. Wiadomości Lekarskie, 59, 679-684.

[21] Hordyjewska, A. and Pasternak, K. (2005) Apoptotyczna śmierć komórki. Advances in Clinical and Experimental Medicine, 14, 545-554.

http://www.dbc.wroc.pl/Content/2100/a05-3-19_Hord.pd $\underline{\mathrm{f}}$

[22] Ola, M.S., Nawaz, M. and Ahsan, H. (2011) Role of Bcl2 family proteins and caspases in the regulation of apoptosis. Molecular and Cellular Biochemistry, 351, 41-58. doi:10.1007/s11010-010-0709-X

[23] Rupinder, S.K., Gurpreet, A.K. and Manjeet, S. (2007) Cell suicide and caspases. Vascular Pharmacology, 46, 383-393. doi:10.1016/j.vph.2007.01.006

[24] Sampath, D., Rao, V.A. and Plunkett, W. (2003) Mechanism of apoptosis induction by nucleoside analogs. Oncogene, 22, 9063-9074.

doi:10.1038/sj.onc. 1207229

[25] Chowdhury, I., Tharakan, B. and Bhat, G.K. (2008) Caspases: An update. Comparative Biochemistry and Physiology B, 151, 10-27. doi:10.1016/j.cbpb.2008.05.010

[26] Inoue, S., Browne, G., Melino, G. and Cohen, G.M. (2009) Ordering of caspases in cells undergoing apoptosis by the intrinsic pathway. Cell Death \& Differentiation, 16, 10531061. doi:10.1038/cdd.2009.29

[27] Korzeniewska-Dyl, I. (2008) Kaspazy-nowy lek w terapii przeciwzapalnej i przeciwnowotworowej? Polski Merkuriusz Lekarski Medpress, 24, 5-7.

[28] Ritter, P.M., Marti, A., Blanc, C., Baltzer, A., Krajewski, S., Reed, J.C. and Jaggi, R. (2000) Nuclear localization of procaspase- 9 and processing by a capsase-3-like activity in mammary epithelial cells. European Journal of Cell Biology, 79, 358-364. doi:10.1078/S0171-9335(04)70040-0 
[29] Fan, T.-J., Han, L.-H., Cong, R.-S. and Liang, J. (2005) Caspase family proteases and apoptosis. Acta Biochimica et Biophysica Sinica, 37, 719-727. doi:10.1111/j.1745-7270.2005.00108.x

[30] Klöpfer, A., Hasenjäger, A., Belka, C., Schulze-Osthoff, K., Dörken, B. and Daniel, P.T. (2004) Adenine deoxynucleotides fludarabine and cladribine induces apoptosis in a CD95/Fas receptor, FADD and caspase-8-independent manner by activation of the mitochondrial cell death pathway. Oncogene, 23, 9408-9418. doi:10.1038/sj.onc.1207975

[31] Marzo, I., Pérez-Galán, P., Giraldo, P., Rubio-Felix, D., Anel, A. and Naval, J. (2001) Cladribine induces apoptosis in human leukaemia cells by caspase-dependent and -independent pathways acting on mitochondria. Biochemistry Journal, 359, 537-546. doi:10.1042/0264-6021:3590537

[32] Nomura, Y., Inanami, O., Takahashi, K., Matsuda, A. and Kuwabara, M. (2000) 2-Chloro-2'-deoxyadenosine induces apoptosis through the Fas/Fas ligand pathway in human leukemia cell line MOLT-4. Leukemia, 14, 299-306. doi:10.1038/sj.leu.2401649
[33] Roterman-Konieczna, I. (2010) Statystyka na recepte. Wprowadzenie do statystyki medycznej. Wydawnictwo Uniwersytetu Jagiellońskiego, Warszawa.

[34] Conrad, D.M., Robichaud, M.R.J., Mader, J.S., Boudreau, R.T.M., Richardson, A.M., Giacomantonio, C.A. and Hoskin. D/W. (2008) 2-Chloro-2'-deoxyadenosine-induced apoptosis in $\mathrm{T}$ leukemia cells is mediated via a caspase3-dependent mitochondrial feedback amplification loop. International Journal of Oncology, 32, 1325-1333.

[35] Pérez-Galán, P., Marzo, I., Giraldo, P., Rubio-Félix, D., Lasierra, P., Larrad, L., Anel, A. and Naval, J. (2002) Role of caspases and apoptosis-inducing factor (AIF) in cladribine-induced apoptosis of B cell chronic lymphocytic leukemia. Leukemia, 16, 2106-2114. doi:10.1038/sj.leu.2402650

[36] Ceruti, S., Beltrami, E., Matarrese, P., Mazzola, A., Cattabeni, F., Malorni, W. and Abbracchiao, M.P. (2003) A key role for caspase- 2 and caspase- 3 in the apoptosis induced by 2-chloro-2'-deoxy-adenisine (cladribine) and 2chloro-adenosine in human astrocytoma cells. Molecular Pharmacology, 63, 1437-1447. doi:10.1124/mol.63.6.1437 